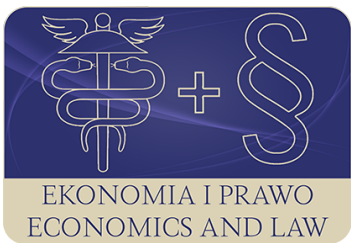

EKONOMIA I PRAWO. ECONOMICS AND LAW

Volume 20, Issue 3, September 2021

p-ISSN 1898-2255, e-ISSN 2392-1625

www.economicsandlaw.pl

ORIGINAL ARTICLE

received 02.05.2021; revised 10.09.2021; accepted 30.09.2021

Citation: Kossecki, P., \& Akin, O. (2021). Valuation of copyrights to audiovisual works: transparency practices of the copyright management organizations in the European Union. Ekonomia i Prawo. Economics and Law, 20(3), 543-571. https://doi.org/10.12775/EiP.2021.033.

\title{
Valuation of copyrights to audiovisual works: transparency practices of the copyright management organizations in the European Union
}

\author{
PAWEE KOSSECKI \\ Polish National Film, Television and Theatre School in Łódź, Film Production Department, Poland \\ $\square$ kossecki@poczta.onet.pl \\ (D) orcid.org/0000-0003-1479-8554 \\ OGUZHAN AKIN \\ corresponding author \\ Kozminski University in Warsaw, Department of Finance, \\ ul. Jagiellońska 57, 03-301 Warszawa, Poland \\ ๑oguzhanakin@windowslive.com \\ (D) orcid.org/0000-0001-9806-8297
}

\begin{abstract}
Motivation: The functioning of the audiovisual sector strongly depends on the use of copyrights and related rights. Problems with their clearing could harm the functioning of companies and might even lead to strong financial problems. The distribution of copyright-protected audiovisual works requires the licensing of rights by different rightsholders. Some of them are represented by Copyright Management Organizations (CMOs), which allow users to clear rights for many works without individual negotiations. Fees paid to CMOs for copyright-protected content constitute a significant part of operating costs for companies like TV stations, cable operators, VoD (Video on Demand) platforms. In case of intellectual properties for audiovisual works, CMOs make the valuation. They have been facing legal challenges due to subjective valuations as a result of being monopo-

lies in the local market of the represented country and lack of transparency.

Aim: This work explores the transparency of $21 \mathrm{CMOs}$ in $4 \mathrm{EU}$ countries due to their expected to be an integrated market status as the result of political and economic amalga-
\end{abstract}


mation. In addition to the adoption of The European Union Directive on collective management of copyright and multi-territorial licensing of rights, as part of the EU's Digital

Single Market project, this exploratory research, with comparative analysis of CMOs using the linear ordering methods, explains the necessity of an epagogic approach to cre-

ating correct institutions besides directives and laws, such as central observation, an ombudsman for conflict management, or an official body to employ these features in one structure to actively govern the market.

Results: The conducted analysis allowed us to reflect on the importance of transparency and taxonomic mapping of the audiovisual market landscape will be the guideline to flatten the copyright valuation divergence in the EU and eventually will pave the way for fewer disputes and more innovations.

Keywords: intangible asset valuation; intellectual property; copyrights; licensing; European Union directive; collective management organizations

JEL: C19; D46; K10; K11; L43

\section{Introduction}

Demmou et al. (2019) state in one of the latest OECD Report that intangible asset class has been among the most significant economic growth driver across all the OECD countries. However, they are radically limited by the valuation hardships and greater asymmetric information. According to Moberly (2014), intangible assets are generally vulnerable to competitive-advantage undermining, value erosion, forging, rights violation, misuse, and compromise when they are not under constant monitoring, supervision, and administration.

Accessibility and consumption features for copyrighted products like audiovisual works are generally vulnerable to piracy, unpaid consumption, and unauthorised access without any permission and payment to the copyright holder. Therefore, even though they are copyrighted, the vulnerability of the audiovisual works is positioning them as semi-excludable and semi-rival types of properties (Caplan, 2013; Gans, 2012; Ostrom, 2010; Webster \& Jensen, 2006). Undoubtfully, this type of market failure is increasing with the developing new and faster, peer-to-peer content sharing capabilities which synchronously reduces the delivered value for work owners and prevents the evolving business models, entrepreneurs and cross-innovation while eroding the social moral when they do not protect the full-excludability and full-rivalry features of the delivered works.

While the protection of the audiovisual works is possible with the copyright and related rights, under the law of the connected country and/or countries, it requires a medium as an enforcer. Due to the abovementioned failures and nature of audiovisual works, their small and medium-sized producers and individual authors have to use a centralised distributor. This type of sizable structure is called Collective (or Copyright) Management Organisations (CMOs). They have the following key roles:

- valuation, tariff, and conditions negotiation;

- enforce copyrights and related rights on behalf of the users; 
- allocate user license to demanding other mediums and end-users;

- identify the possible piracy, unpaid consumption, and unauthorised access;

- follow the legal proceedings;

- eventually collect the payments (royalties) on behalf of the copyright holders (CISAC, 2021).

Along with all the stated organizational tasks, CMOs are also responsible to set the tariffs with a valuation method they prefer to use based on existing practices or developing a new one that is prone to be subjective. Whilst the calculation of the intangible assets is already not standardized, on the other hand, it is also hard to reach perfect competition in the market with the tariffs of the CMOs since they are de facto monopolies (WIPO, 2016). This has been a long-debated topic for most scholars, regulators, and market participants. There have been also numerous legal disputes among CMOs, licensees and copyright holders due to non-standard, subjective, and generally non-disclosed valuation practices.

The emergence of the first law in this sensitive area is in 1624, The Statute of Monopolies and afterwards in 1710 the British Statute of Anne (Brad \& Bently, 1999). It can be said that Europe has taken more serious law implications in copyrights matter with a leading position as early as 1886 when the Berne Convention for the Protection of Literary and Artistic Works was signed and revised eight times until 1979 (WIPO, 2020). Furthermore, since the Directive of the European Parliament and of the Council of 22 May 2001 on the harmonisation of certain aspects of copyright and related rights in the information society (2001), European Union has been trying to adapt to the digital era and prepare the union for digitalisation and upcoming copyright challenges with followed directives: Directive of the European Parliament and of the Council of 26 February 2014 on collective management of copyright and related rights and multi-territorial licensing of rights in musical works for online use in the internal market (2014) and Directive of the European Parliament and of the Council of 17 April 2019 on copyright and related rights in the Digital Single Market and amending Directives 96/9/EC and 2001/29/EC (2019), under the EU's Digital Single Market project.

Consequently, this study explores the audiovisual market landscape of different CMOs in the European Union and their regulated or non-regulated valuation practices with multilayered comparisons which will be the guideline to flatten the copyright valuation divergence in the union and eventually will pave the way for less disputed and more innovated Digital Single Market project.

\section{Literature review}

The need for such a sizeable structure to protect the authors' rights first appeared in France. In 1777, the Society for dramatic legislation 'Bureau de Législation Dramatique' was established by 22 playwrights which is today's base of the Society of Dramatic Authors and Composers-SACD 'Sociéte des Auteurs et Compositeurs Dramatiques' (SACD, 2021). As can be seen, the idea of col- 
lective management is two and half centuries old and more than 500+ CMOs are acting as national monopolies all over the world. Though understanding of copyrights and the practices of their related rights have not been transformed significantly, yet includes granting licensing, administrating, protecting, collecting royalties, and distributing the remunerations, valuating, creating tariffs and representing the right owners in negotiations and court trials with the presumption (Kossecki, 2015; Kossecki et al., 2021). In collective management, all the abovesaid practices are the straightforward reflections of authors' direct copyright and related rights except for the valuation.

The most significant added value of the CMOs, as a medium, is the valuation which is the most challenging part for this type of asset class and the main source of the disputes due to its inexact cost items and subjectivity. This inconspicuous calculation service with collective management fees brings a significant expense item for media. According to Kossecki (2015), the cost of licensing fees for broadcasted and rebroadcasted copyright-protected works for TV stations, cable operators and $\mathrm{VoD}$ platforms, ranges from $25 \%$ to $50 \%$ of their retransmission revenue. Moreover, in most cases, dealing with more than one $\mathrm{CMO}$ is the requirement for this industry which inflates the overall costs. Furthermore, the potential abuse of the market position, absence of definite legal procedures and efficient calculation systems are the sources of rising valuation disputes in the European court cases, as the valuation practices and related laws are particularly disintegrated (Hooijer \& Baloyi, 2016).

By the adjudicated rulings of the European Court of Justice, by the nature of the represented rights and by the connotation of art. 102 Treaty on the Functioning of the European Union (ECJ Case 395/87, 1989; ECJ Case 402/85, 1987; ECJ Case C-351/12, 2014; ECJ Case C-52/07, 2008) CMOs are positioned as a monopoly in their represented territories. Another adjudicated ruling of the European Court of Justice stated that, where such a collecting society imposes fees for its services which are appreciably higher than those charged in the other Member States and where a comparison of the fee levels has been made consistently, that difference must be regarded as indicative of an abuse of a dominant position within the meaning of Article 102 TFEU. In such a case it is for the collecting society in question to justify the difference by reference to objective dissimilarities between the situation in the Member State concerned and the situation prevailing in all the other Member States (ECJ Case 395/87, 1989; ECJ Case C-351/12, 2014; ECJ decision in Joined Cases 110/88, 241/88 and 242/88, 1989). In the judgement of the ECJ Case C-52/07 (2008), the valued price of the work was ruled as excessive by the court compared to the economic value of the delivered service by the CMO. Eventually, in the early ages of the audiovisual market, courts also ruled as the value of the copyrights listed in tariffs by the CMOs do not fit the definition of the market price considering the fair market value due to their predominant representation with entrepreneurial characteristics (ECJ Case 395/87, 1989; ECJ Case 402/85, 1987). 
As stated in Kossecki et al. (2021), the way royalties are calculated by the CMOs for the remuneration is usually based on the following methods:

- lump sums based on the number of users or delivered services;

- percentage system - the level of royalties is calculated as a per cent of revenues;

- mixed systems.

Additionally, the following conventional methods for the valuation of copyrights are being adopted (Gilbert, 2009; Kossecki, 2012; 2015; 2020; Pastor, et al., 2017; Rumniak, 2011; Smith \& Parr, 2005):

1. Income approach, a higher level of royalties can be related to obtaining more revenue from copyright users (ECJ Case 395/87, 1989). The income approach is easier to apply when the copyright user does not pay other license fees to copyright holders and receives a blanket license, which grants unlimited authorization to access the repertoire of a CMO. The partition coefficient between the licensor and licensee should be indicated based on the economic value added of copyrights. In case of limited data, the 25 per cent Rule of Thumb can be used (licensor should obtain $25 \%$ of operating profit generated by the intellectual property, while $75 \%$ should be retained by the licensee). The exception will apply only to the film industry, where due to the higher number of different rightholders, its use will be less frequent. The percentage (importance) of elements considered in the total price of the service indicates part of the value of the service generated by copyrights.

2. Market comparison, due to the dominant position of CMOs on national markets, the prices cannot be considered as a market value. The market comparison assumes that free-market supply and demand will create an equilibrium price (Depoorter \& Parisi, 2002). If fees charged by a copyright collecting society are much higher than ones in comparable foreign markets, it is possible to assume an abuse of the dominant position by a given CMO. If fees charged in different countries are compared, it is necessary to consider specific market characteristics, i.e., their geographical/economic position (Kossecki, 2012; 2014). To apply international measures of comparison, several first steps are necessary (Kossecki, 2015):

- indicating comparable markets;

- assessment of global charges for all CMOs based on the international comparison;

- choice of a proper multiplier, usually percentage or lump sum;

- calculation of royalty rate for CMOs based on the economic use of the repertoire and profits;

- calculation of royalty rate for specific CMOs.

3. Cost approach, in a broader term, this method assesses the cost of value creation. Due to the limited relationship between the level of income created by the assets in the case of copyrights and the cost of asset creation, the cost 
approach based on the value of assets (ability to generate future income) and cost of their creation is not used for CMOs' fees valuation.

The lack of transparency, which is the base for subjective valuation practices of European CMOs, places them in a position of monopolists. Paving the way to less dispute and more innovation requires clear judiciary steps that include creating correct institutions besides directives and laws, such as a central observation, an ombudsman for conflict management, or an official body to employ these features in one structure to actively govern the market. A first crucial step would be mapping the audiovisual market landscape to develop clearer guidelines that will flatten the copyright valuation divergence.

\section{Methods}

For the institutions that hold a monopolistic position in a market like CMOs, it has been arguably hard to explore their fairness in the market and correctness in the valuation due to a lack of accurate data. Thanks to the digitalization and the enforcements of the jurisdictions, there are more and more data made publicly available by the CMOs. In the EU, a series of directives to start with the Green paper on copyright and related rights in the information society (EU, 1995), have been trying to amalgamate the common markets for intellectual property rights and aiming to create a Digital Single Market under the European Union's Single Market project (European Commission, 2015).

\subsection{Research origination}

Analysing the effect of various CMOs in the EU requires taking a closer look at respective countries and CMOs' local practices. Such an attempt of comparison requires a defined categorization of countries in question, which for the purpose of this study was based on the countries' classification presented in the research of Kossecki et al. (2021), whocompared 22 European Union countries via partitioning them into 4 clusters with K-means Method basing on their similar market characteristics variables:

- purchasing power adjusted Gross Domestic Product per capita (GDPpc);

- CMOs collection as a per cent of GDP (CMOcol);

- mean consumption expenditures of private households on cultural goods and services (MeanCons).

The most representative country per cluster was chosen to start this study. The criteria based on which they have been defined are: their continuity to the EU single market membership, Euro area participation to lower the different currency effect and,most notably, their position to the centroid of the respective cluster, in terms of the abovementioned variables, to accept them as comparable and characteristic for the represented clusters that can be seen in Table 1.

This study investigated 21 CMOs in these 4 representative countries further in detail to capture the full understanding of valuation practice divergences 
in similar market clusters of the EU along with other transparency indicators, such as financial and descriptive features.

Description of the countries' copyright remuneration income model is presented with an emphasis on revenues from cable emission of audiovisual materials (for some CMOs, tariffs for terrestrial broadcasters are considered due to lack of data). With the specific tariffs being set on a national level, it is worth taking a close look at the rates and remuneration models adopted in each country to proceed with a deeper analysis for CMO clusters.

\subsection{Used methods}

CMOs were investigated in two stages. In the first stage, exploratory multilayered comparison research was conducted to show their subjective approaches to pricing practice along with the availability of their data and its interpretation among clusters:

- availability of their tariff calculation methods, valuation information with their price units, whether there is a law or internal bylaws this valuation relies on;

- availability of their annual reports, financial statements (balance sheet, cash flow and income statement), transparency report for the details of the organization and whether there is independent auditing for these reports;

- availability of any information regarding a possible dispute, such as the number of legal cases settled or ongoing, and any statement that shows the path to resolution;

- information availability in second or more languages besides the national language including the website, subpages, and documents;

- availability of the price and tax information, rate of the tax and price itself (authors included VATs in the tables when not included in the price lists to make them comparable);

- availability of financial information with their total revenue from the latest annual report published, their total expenses if stated and calculated remuneration to distribute. Expenses or remunerations are estimated by the authors when not stated.

In the second stage of the research, a comparative analysis was carried out to rank the surveyed CMOs in terms of the elements of transparency mentioned above. The method of standardized sums was used, as described in more detail, e.g., by Dziechciarz (2002). The method of standardized sums is one of the methods of linear ordering that allows conducting a multivariate comparative analysis, which allows studying complex phenomena described employing many variables. Linear ordering methods rank objects from worst to best. To conduct the analysis, it is necessary to define the nature of all variables describing a given phenomenon which may be:

- stimulant - an increase indicates an increase in the level of a complex phenomenon; 
- destimulant - a decrease indicates an increase in the level of the complex phenomenon;

- nominant - a given value indicates the highest level of a complex phenomenon, while smaller and larger ones indicate a lower level;

- neutral - the values do not indicate the level of a complex phenomenon.

In the case of the standardized sum method, it is assumed that the variables are standardized and that they are all stimulants. Destimulants and nominants come down to the form of stimulants.

Let assume that $n$ objects are assigned the values of the variables $\mathrm{X}_{1}, \mathrm{X}_{2}, \ldots$, $X_{m}$. The value of the variable $X_{j}$ for the $i$-th object is marked $x_{i j} ; 1 \leq i \leq n, 1 \leq j \leq m$. The standardized variables $Z_{1}, \ldots, Z_{m}$ correspond to the variables $X_{1}, \ldots, X_{m}$, defined by the dependence:

$$
z_{i j}=\frac{x_{i j}-\bar{x}_{j}}{s_{j}},
$$

where:

$z_{i j}$ - value of the standardized variable $Z_{j}$ for the $i$-th object;

$x_{i j}$ - the value of the $\mathrm{X}_{\mathrm{j}}$ variable for the $i$-th object;

$\bar{x}_{j}$ - arithmetic mean of variable $\mathrm{X}_{\mathrm{j}}$;

$s_{j}-$ standard deviation of the variable $\mathrm{X}_{\mathrm{i}}$.

Using the standardized sum method in the first stage, the weighted sums of the variables are calculated for each object according to the formula:

$$
p_{i}=\sum_{j=1}^{m} z_{i j} w_{j},
$$

where $w_{j}$ is the weight of the $j$-th variable.

The values of the weights $w_{j}$ are intended to determine preferences for individual variables describing a complex phenomenon, while the following conditions must be met:

$$
\begin{aligned}
& w_{j} \geq 0, \\
& \sum_{j=1}^{m} w_{j}=1 .
\end{aligned}
$$

Then the so-called development measures are calculated:

$$
m_{i}=\frac{p_{i}-p_{\min }}{p_{\max }-p_{\min }},(i=1, \ldots, n),
$$

where:

$$
p_{\max }=\sum_{j=1}^{m} z_{\max , j} w_{j},
$$




$$
p_{\min }=\sum_{j=1}^{m} z_{\min , j} w_{j}
$$

$z_{\text {max }, j}$ and $z_{\text {min, },}$ are the values for abstract objects, pattern and anti-pattern, respectively, determined as follows:

$$
\begin{aligned}
& z_{\max , j}=\max _{i} z_{\ddot{u}}, \\
& z_{\min , j}=\min _{i} z_{\ddot{u}} .
\end{aligned}
$$

The measures of development meet the condition: $0 \leq m_{i} \leq 1$.

CMOs were awarded a certain number of points for the presence of a specific element, then the obtained number of points was summed up and divided by the maximum number of points possible to obtain in a given area. In this way, values ranging from 0 to 1 were obtained and these values were standardized, which ensures higher transparency and comparability of indicator values. In the conducted comparative analysis, the following areas were examined:

1. availability of the tariff calculation and valuation information (3 total points):

- price unit (1 point);

- calculation method (1 point);

- enforcing power (law, internal policy etc.) (1 point);

2. availability of activity reports (4 total points):

- annual report (l point);

- financial statement (1 point);

- transparency report (1 point);

- independent auditor (l point);

3. availability of the dispute related information (2 total points):

- dispute resolution statement (1 point);

- number of court disputes (1 point);

4. availability of representation data in the market (3 total points):

- number of represented works (1 point);

- number of represented members (1 point);

- number of served clients (l point);

5. availability of the price and financial information (3 total points):

- price (l point);

- vat information (1 point);

- financial disclosure (l point);

6. availability of the information in different languages (3 total points):

- national language (1 point);

- English (1 point);

- other (1 point). 


\section{Results}

\subsection{Portugal}

Portugal represents the Cluster 1 countries of the EU, with 5 CMOs examined. There was no data found for Pl Motion Picture Licensing Company (MPLC) (MPLC, 2019). P2 Sociedade Portuguesa de Autores (SPA) is the biggest and only multilingual CMO in Portugal per available data, however, has no specific price list due to $10 \%$ tariff exercise from annual operating income of a Cable Operators with no VAT inclusion or exclusion information, based on their internal bylaws. Fees for TV broadcasters ranges per channel and usage rate set in 2012 presented in Table 2. There is also a minimum fee of EUR 6,000 per annum for non-profit small and micro TV broadcasters where such diversion does not exist in most of the CMOs (SPA, 2012; 2019; 2020; 2021). P3 Gestão dos Direitos dos Artistas (GDA) is the second biggest CMO in Portugal in size and total revenue, according to available data, with no pricing information (GDA, 2019). There was no data found for P4 Audiogest like MPLC (P1). P5 Associação para a Gestão Coletiva de Direitos de Autor e de Produtores Cinematográficos e Audiovisuais (GEDIPE) is the only independently audited CMO with only price information per user ranges, per month with no VAT information and prices marked up by Portuguese Consumer Price Index (CPI), please see Table 3. Also, it has the most extensive Dispute Resolution Statement in the study (Gedipe, 2020a; 2020b; 2021).

Among the four countries in this study, Portugal has the least transparent CMOs with only $26 \%$ of overall data availability based on the set criteria. Descriptive representation is slightly higher with $32 \%$ of data availability compared to numeric representation with up to $20 \%$. Even though it has the most extensive Dispute Resolution Statement in the study its availability is limited to one CMO only and none of the CMOs mention number for the amount of legal dispute they involved. Information is available mostly in the national language with limited valuation insights and tariffs. Furthermore, based on estimations, Portugal has the lowest total revenue, against the other three countries, and distributed remuneration to its members with $63.76 \%$ while causing the second-highest expense with the ratio of $14.69 \%$ right after Slovenia.

\subsection{Slovenia}

Slovenia represents the Cluster 2 countries of the EU, with 4 CMOs examined. The first CMO examined is S1 Združenje Avtorjev In Nosilcev Malih In Drugih Avtorskih Pravic Slovenije (Zamp - Združenje Avtorjev Slovenije). It is the second biggest CMO in Slovenia, regarding the number of members around 60,047, as well as the biggest one, regarding the total expense ratio around $42.82 \%$. The tariff for a cable operator, with VAT (9.5\%) included by the authors, is EUR 
0.0102 per user, per month; however, declared as without VAT in the price list which is common for all CMOs in Slovenia. The valuation method of this CMO is negotiated upon the call of the Republic of Slovenia and published on the Official Gazette of the RS, No. 27/2016 of 11 April 2016, which makes it the only CMO in Slovenia to value through external enforcement (ZAMP, 2019; 2020; 2021). S2 Združenje Sazas is the biggest CMO, with 12 million represented works, 7,083 clients and the biggest total revenue. The valued price is EUR 0.3066 per user, per month; however, declared without VAT in the tariff. S2 is one of the two CMOs that revealed the number of legal disputes they are in, and the only CMO that detailed this information as 809 settled cases out of 1239 total disputes (SAZAS, 2006; 2018; 2019). The tariff might change according to separate agreements, broadcasting retransmissions or secondary broadcasts in terms of their cast, form, and character, which one of the examples can be seen in Table 4. S3 Zavod Za Uveljavljanje Pravic Izvajalcev In Proizvajalcev Fonogramov Slovenije (Ipf) is the second CMO in the study with legal dispute numbers available as 30. The valued price for 2021 is EUR 0.0854 per user, per month without VAT. S3 has the only price list calculated in advance for 6 years (from 2018 to 2023) in this study, however, there is no calculation method available. The estimated total expense ratio is the second-highest in Slovenia with $41.94 \%$. Even though the information is available in English and the national language, the number of represented works and clients are not available (IPF, 2005; 2018; 2019; 2021). S4 Zavod za uveljavljanje pravic avtorjev, izvajalcev in producentov avdiovizualnih del Slovenije, k.o. (AIPA, k.o.) is one of the smallest CMOs in Slovenia, hence, marked the highest remuneration ready to distribute with $71.02 \%$ with the lowest total expense rate of $28.98 \%$. S4 lists the highest price among the Slovenian CMOs with EUR 0.9417 per 50 connection, per month without VAT, through negotiation and the following tariff criteria (AIPA, 2011; 2019; 2021):

- scope of the repertoire;

- the scope of the permit;

- the revenue generated by the use of the copyrighted work or, failing that, the costs associated with that use;

- the importance of the author's work for the user's activity;

- the relationship between the protected and unprotected copyrighted works used;

- the relationship between rights-managed collectively or individually;

- the special complexity of collective rights management due to the specific use of copyrighted works;

- comparability of the proposed tariff with the tariffs of the same kind of collective organizations on the same kind of works for the same kind of use in the Republic of Slovenia and the other Member States, considering the gross domestic product per capita in purchasing power unit.

With a $75 \%$ overall ratio, Slovenia is the most transparent and regulated country in this study per pre-set criteria including both descriptive representa- 
tion (58\%) and numeric representation (92\%). On the other hand, Slovenia has the highest expense ratio of $33.3 \%$ along with the second-lowest remuneration ready to distribute ratio of $66.7 \%$ and total revenue per population right after Portugal. Furthermore, there was no dispute resolution statement available for any of the CMOs, while this is the only country the number of legal disputes information was declared, both facts might be the result of existing high regulation.

\subsection{Finland}

Finland represents the Cluster 3 countries of the EU with 6 CMOs examined. Fl Kopiosto is the biggest CMO in Finland with 50,000 members and one of two CMOs in the country where neither financial statement nor independent auditor was declared. The single price list strategy in Table 5 is per household, per month with VAT (10\%), without calculation method, where the HD channels are billed separately and not declared anywhere (Kopiosto, 2019; 2020; 2021). F2 Teosto is the second biggest CMO with 34,353 members and the biggest in terms of total revenue with an available calculation method. The price per channel, per household, per month with VAT (10\%) is EUR 0.0066. The blanket license calculated based on the audiovisual service provider's total revenue follows with deductible items such as yearly volume and cash discounts given to media agencies, credit losses relating to total revenue and VAT (Teosto, 2018; 2019a, 2019b, 2021).

total revenue - deductible items $=$ revenue subject to royalty,

revenue subject to royalty $*$ royalty percentage $=$ performing rights royalty. $(11)$

F3 Gramex is the only CMO where all the numbers of works $(56,174)$, members $(16,119)$ and clients $(31,000)$ are available. EUR 4.1200 is the price per second with VAT (24\%) and a calculated average of the following 4 categories charged by the CMO: television drama, music program and music documentary, a TV documentary or short film and other television programs (Gramex, 2019a; 2019b; 202la; 2021b). F4 Filmex has the highest total expense ratio in Finland with $32 \%$ and is the only CMO where there is no certain price for cable operators. The calculation of the actor's compensation has considered the quality, amount, and year of payment of the actor's initial fee, the year of broadcast, length, and time of the program to be replaced. The personal compensation of the rightholders is usually based on the rightholders' employment contract, the applicable collective agreement, or the agreement between the user and Filmex. In the annual calculation of accountable claims, CMO uses a combination of an index (Filmex index - no insight available for indexing criteria) and a program age in a formula as follows (Filmex, 2019a; 2019b; 2021): 
- program category i (years: $5-9)=((0+$ index $) / 1)$;

- program category ii (years: $10-34)=((1+$ index $) / 2)$;

- program category iii (years: $35-49)=((2+$ index $) / 3)$.

F5 Muusikkojen Liitto is the only CMO without any report publication and limited information. The tariff is EUR 0.0141 per performance, per second, without any VAT information (FMU, 2018; 2021). F6 Nordisk Copyright Bureau has no shared numbers of representation size in the market and has the second-highest expense ratio of $27.30 \%$. The declared tariff is EUR 2 per second, without any VAT information. 6F and 3F are the only CMOs with dispute declarations available on their websites (NCB, 2019; 2020; 2021).

Finland and Slovenia are the only countries where all the CMOs declared the unit of their price list. Different from others, most of the CMOs keep their information in three languages, Finnish, Swedish and English. Finland comes as the third country in information availability of $56 \%$ (with a score of $50 \%$ descriptive and $61 \%$ numeric) in defined availability scores and close to Portugal regarding the percentage of the total expense ratio with $13.6 \%$. On the other hand, Finland is the leader in terms of the number of members' declaration scores, total revenue per population and ready to distribute remuneration ratio of $86.4 \%$ which is slightly above Austria in this category. Lastly, a more methodological approach to the valuation can be seen with the available information, even though the method declaration score is around the average of the studied countries.

\subsection{Austria}

Austria represents the Cluster 4 countries of the EU, with 6 CMOs examined. The first $\mathrm{CMO}$ is $\mathrm{Al}$ Autoren, Komponisten und Musikverleger (AKM). It is the biggest in terms of total revenue and number of members in the country and the best performer in terms of remuneration distribution with $91.63 \%$ in the study. The tariff is EUR 0.0391 per household, per month, without VAT. The basis of calculation is the net assessment which is all net income from advertising, sponsorship, placement, and other advertising-like activities or contributions and/or from other grants (other income) before the surcharge of sales tax and advertising tax. The net assessment base also includes any (immediate or indirect) consideration that the licensee receives from a third party (AKM, 2019a; 2019b; 2020; 2021). The second CMO is A2 Interpreten und Produzenten von Tonträgern und Musikvideos (LSG) which is the second biggest CMO in Austria in terms of number of members. The set tariff is EUR 0.2716 per household, per month, without VAT. The calculation basis and dispute resolution are not available (LSG, 2016; 2019; 2021). A3 Literar-Mechana is the only CMO in Austria that reports the numbers of represented works, members, and clients, and the leading $\mathrm{CMO}$ in the study with the lowest expense ratio of $6.66 \%$. The set tariff is EUR 4.8192, with no information regarding unit, tax, or method of calculation (LM, 2016; 2019; 2021). A4 Motion Picture Licensing Company 
(VAM) has a high number of represented works $(242,341)$ and the lowest number of members (320). The set price list is EUR 0.7129 per household, per quarter, without VAT, according to the statutes of the arbitration commission. A4 is the worst performer in terms of remuneration distribution, with $68.90 \%$ among others in the country, and no annual report is available on their website (VAM, 2019; 2020; 2021a, 2021b). A5 Rechte und Ansprüche der Filmschaffenden (VDFS) set its tariff to EUR 4.7827, with no unit information tax, or method of calculation as well as the annual report (VDFS, 2016; 2020; 2021). Additionally, it has the highest total expense ratio with $15.51 \%$ in the country. The last $\mathrm{CMO}$ is the A6 Rechte und Ansprüche der Rundfunkunternehmer (VGR) as the only $\mathrm{CMO}$ with no representation related information in the country as well as an annual report (VGR, 2016; 2019; 2020).

Austria gives a view of a regulated country in terms of copyrights and related rights along with Slovenia. All the CMOs report financial statements and transparency reports and almost all the CMOs have a dispute resolution statement and/or guidance on their website with cited local law articles. It has the second-highest information availability score in the study, with a $63 \%$ ratio and the highest average price list per CMO in the study by EUR 1.9454. Austria comes as second in total revenue and distributed revenue per capita, right behind Finland, while it is the best performer with the lowest average total cost in the study by the ratio of $8.96 \%$.

\subsection{Comparative analysis}

This part of the work describes the results of the conducted quantitative comparative analysis and Table 6 represents the assigned values of synthetic indicators with the usage of formula (1). The statistical characteristics of synthetic indicators of transparency are summarized in this data which presents the relatively high values of synthetic transparency indicators in terms of availability of the tariff calculation and valuation information, and availability of the price and financial information while the lowest values in terms of availability of the dispute related information and availability of the information in different languages. Furthermore, the availability of representation data in the market appeared as average in comparison. It should be noted that the method of calculating the indicators does not ensure full comparability, but only shows the distance between the obtained value and the possible maximum value.

The value of arithmetic means and standard deviations of the variables $\mathrm{X}_{1} \ldots$, $\mathrm{X}_{6}$ are presented in Table 7 , while the values of the standardized variables $\mathrm{Z}_{1}, \ldots$, $\mathrm{Z}_{6}$ are in Table 8. All indicators were considered stimulants. The calculated values of the indicators were multiplied by the weights given in Table 9, obtaining the weighted sums of the variables (Table 10). When determining the values of the weights, due to the difficulty of precisely diagnosing the impact of individual elements on the transparency, we tried to distribute the weights as evenly as possible among individual areas. Each area was assigned a weight of 0.18, ex- 
cept for the area of availability of the information in different languages, which due to relatively lower expectations from CMOs, was given a weight of 0.1 . With better knowledge of the issue, different weights can be assigned to the studied areas.

The next step was to determine the values of the pattern and anti-pattern abstract objects with the best and worst values, respectively, for each variable (Table 11), using the dependencies (6) and (7). In the final stage, the values of the development measures were calculated (3) (the values of the transparency measures are in the range $[0 ; 1]$; the higher their value, the higher the level of the complex phenomenon). The summary of the results is represented by the statistical characteristics listed in Table 12, while Table 13 lists the sorted values of standardized transparency indicators for the pattern and the anti-pattern from highest transparency to lowest.

Slovenia obtained the highest value according to the category of transparency measure in the countries comparison, while the CMOs of Slovenia are placed on the top of the list. Portugal placed as a country and the Portuguese CMOs themselves are ranked lowest in terms of the transparency measure values. Austria is listed as the second country in the comparison even though its CMOs could not get ranked among the first five. However, they are cumulated close to each other which shows their evenly reflected transparency level. This feature is not visible in Finland, since its CMOs are not closely listed to each other and they have shown different levels of transparency that indicates less standardized laws and internal policies for Finland.

\section{Conclusion}

Valuation of intangible assets is known for their unstandardized methods of calculation and complications as the results of countless variable factors and cost items. The valuation method itself is a piece of important information to share with all the stakeholders to understand the fairness of the real value and its reflection. Lack of transparency on the subject of calculation methodology along with other relevant data investigated in this study has been the main source of legal dispute for the CMOs and their counterparties.

Different ways of calculating the remunerations for CMOs paid by cable operators in the examples of this study exist within the European Union. While most of the valuation techniques are not clear, others may constitute fixed amounts, depending on the number of subscribers, of channels retransmitted, type of programs transmitted, or the remuneration as a certain percentage of the revenues. When analyzing the number of charges, it should be remembered that in some countries CMOs try to increase rates to an unreasonable level, which causes litigation. On specific markets, during ongoing negotiations or legal disputes, cable operators demand that individual collective management organizations prove the rights represented. 
Moreover, the absence of standardization in the copyrights and related rights management across the EU countries is visible. In overall comparison, declared prices and their units, valuation methodologies, tax practices, published reports, dispute resolution guidance, multilingualism due to globality of such products and audience, regulations, and the number of market shares either not available or distinctly diverse from each other, even though there are some nationwide consistencies due to domestic regulations.

Portugal, as the representative of Cluster 1 countries, shows poor regulation practices regarding transparency, where almost none of the CMOs reveal their prices and related data along with high running costs, lowest average remuneration to distribute and no legal or internal guidance to dispute resolution in place. On the other hand, Slovenia reflects the strongest transparency practices and the lowest average cost for cable operators. However, CMOs report the highest operating costs in the study that might be one of the results of strong regulation, and reporting practices eventually reduces the average remuneration ready to distribute. Finland falls into the $3^{\text {rd }}$ rank in most of the classifications, slightly behind the other countries, nevertheless, shows the strongest multilingual representation and densely regulated market. Furthermore, Finland is head-to-head with Austria in terms of efficiency, as the $2^{\text {nd }}$ lowest average running cost and the highest average remuneration distributer. Lastly, Austria is also another densely regulated market, with the best performing CMOs in terms of lowest average running costs and $2^{\text {nd }}$ highest average remuneration distribution, while being the most expensive market in terms of average price per $\mathrm{CMO}$ and the average cost for cable operators.

Even though, Kossecki et al. (2021) clustered the EU countries according to their purchasing power adjusted Gross Domestic Product per capita, CMOs' collection as a per cent of GDP, and mean consumption expenditures of private households on cultural goods and services at macro level, the expected transparency and management practices of the CMOs shows irregularities and divergence from such clustering sequence except for the average price rates per $\mathrm{CMO}$. As a specific example, although CMOs in Austria collect a much lower percentage (0.031) than Finland (0.045) and Slovenia (0.038), which is the result of high prices and costs to a cable operator found in this study, they perform the lowest average running cost overall.

As it is seen, no country can domestically employ the best practices without failing in the pitfalls where the institutions like CMOs act like a monopoly. Therefore, in an expected to be an integrated market like the European Union as the result of political and economic amalgamation, it is necessary to define the problems of intangible assets valued by unstandardized methods and enable the sharing of the best practices and transparency across the union. Consequently, adoption of the Directive of the European Parliament and of the Council of 26 February 2014 on collective management of copyright and related rights and multi-territorial licensing of rights in musical works for online use in the internal market (2014), as part of the EU's Digital Single Market project, needs to create correct 
institutions besides directives and laws, such as a central observation, an ombudsman for conflict management, or an official body to employ these features in one structure to actively govern the market with specialized experts.

Therefore, we believe that policymakers in the European Union should take into consideration this article to broaden the transparency investigation and continue to develop the EU's Digital Single Market project with regulations. As it has been proven in the results of this article, there are nationwide monopolies, with no standard accountability requirements. This will be the biggest drawback of the planned unionwide Digital Single Market. Hence, this article also guides to need for expert intermediary institutions since results point to the differences between national market structures, practices, and economic magnitude for the society in the union.

\section{Limitations}

The features represented by the historical legal form of the CMO, whether it is an entity forming part of the state administration, whether it is a statutorily-regulated CMO, whether it is a voluntary CMO or private, has had implications on the tariff levels set by the CMO concerned. Valuation levels have also been influenced by whether it is a multidisciplinary or uni-disciplinary $\mathrm{CMO}$ or whether the $\mathrm{CMO}$ is a multi-work or single-work CMO. Additionally, the bundle of rights managed by the $\mathrm{CMO}$, depending on the scope of rights represented, impacts the valuation and pricing (WIPO, 2016). Besides the possible language and translation barriers, some technical difficulties might have impacted the research along with a limited number of countries studied as the cluster representatives. Further research on other cluster representatives, with magnified details, might deliver substantially important shreds of evidence to understand the practices investigated in this study.

\section{References}

AIPA. (2011). Skupni sporazum. Retrieved 13.03.2021 from http://www.aipa.si/ media/uploads/files/qmHTRGvPYeoK.pdf.

AIPA. (2019). Letno poročilo. Retrieved 13.03.2021 from http://www.aipa.si/ media/uploads/reports/WsUuLLfPqolNV.pdf.

AIPA. (2021). Joint agreement. Retrieved 13.03.2021 from http://www.aipa.si/ sl/Dokumenti/Tarifa.

AKM. (2019a). Annual report. Retrieved 13.03.2021 from https://www.akm. at/en/wp-content/uploads/sites/2/2020/07/AKM_AnnualReport19_online_engl.pdf.

AKM. (2019b). Transparenzbericht. Retrieved 13.03.2021 from https://www. akm.at/wp-content/uploads/2020/06/AKM-Transparenzbericht-2019. pdf. 
AKM. (2020). Autonomer Tarif für kommerzielles Privatfernsehen. Retrieved 13.03.2021 from https://www.akm.at/wp-content/uploads/2020/l1/ AT-AKM-fuer-kommerzielles-Privatfernsehen-ab-1.11.2020.pdf.

AKM. (2021). Mandatory publications. Retrieved 13.03.2021 from AKM: https://www.akm.at/ueber-uns/pflichtveroeffentlichungen.

Brad, S., \& Bently, L. (1999). The making of modern intellectual property law: the British experience. Cambridge University Press.

Caplan, B. (2013). Semi-rivalry and fiscal externalities. Retrieved 27.02.2021 from https://www.econlib.org/archives/2013/06/semi-rivalry.html.

CISAC. (2021). The role of collective management organisations. Retrieved 27.02.2021 from https://www.cisac.org/Newsroom/expert-articles/ role-collective-management-organisations.

Demmou, L., Stefanescu, I., \& Arquié, A. (2019). Productivity growth and finance: the role of intangible assets, a sector level analysis. Retrieved 27.02.2021 from http://www.oecd.org/officialdocuments/ publicdisplaydocumentpdf $/$ ? cote $=\mathrm{ECO} / \mathrm{WKP}(2019) 16 \&$ docLanguage $=\mathrm{En}$.

Depoorter, B., \& Parisi, F. (2002). Fair use and copyright protection: a price theory explanation. International Review of Law and Economics, 21(4), 453473. https://doi.org/10.1016/S0144-8188(01)00071-0.

Directive (EU) 2019/790 of the European Parliament and of the Council of 17 April 2019 on copyright and related rights in the Digital Single Market and amending Directives 96/9/EC and 2001/29/EC (OJ L 130, 17.5.2019).

Directive 2001/29/EC of the European Parliament and of the Council of 22 May 2001 on the harmonisation of certain aspects of copyright and related rights in the information society (OJ L 167, 22.6.2001).

Directive 2014/26/EU of the European Parliament and of the Council of 26 February 2014 on collective management of copyright and related rights and multi-territorial licensing of rights in musical works for online use in the internal market (OJ L 84, 20.3.2014).

Dziechciarz, J. (2002). Ekonometria. Akademia Ekonomiczna we Wrocławiu.

ECJ Case 395/87. (1989). ECJ decision in Ministere Public v Jean-Louis Tournier. Retrieved 01.03.2021 from https://eur-lex.europa.eu/legal-content/EN/ TXT/ ?uri=CELEX\%3A61987CJ0395\&qid=1614628268840.

ECJ Case 402/85. (1987). ECJ decision in G. Basset vs. SACEM. Retrieved 01.03.2021 from https://eur-lex.europa.eu/legal-content/EN/ TXT/?uri=CELEX\%3A61985CJ0402\&qid=1614628090758.

ECJ Case C-351/12. (2014). ECJ decision in Ochranný svaz autorský pro práva $k$ dílům hudebním o.s. (OSA) v Léčebné lázně Mariánské Lázně a.s. Retrieved 01.03.2021 from https://eur-lex.europa.eu/legal-content/EN/TXT/ $\mathrm{PDF} /$ ?uri=CELEX:62012CJ0351\&from $=\mathrm{EN}$.

ECJ Case C-52/07. (2008). ECJ decision in Kanal 5 Ltd, TV 4 AB v Föreningen Svenska Tonsättares Internationella Musikbyrå. Retrieved 01.03.2021 from https://eur-lex.europa.eu/legal-content/EN/ TXT/ ?uri=CELEX\%3A62007CA0052\&qid=1614628381363. 
ECJ decision in Joined Cases 110/88, 241/88 and 242/88. (1989). Francois Lucazeau $v$ Societe des Auteurs, Compositeurs et Editeurs de Musique (SACEM) and SACEM v Xavier Debelle and Christian Soumagnac. Retrieved 01.03.2021 from https://eur-lex.europa.eu/legal-content/EN/ TXT/?uri=CELEX\%3A61988CJ0110\&qid=1614628663431.

EU. (1995). Green paper on copyright and related rights in the information society. Retrieved 12.03.2021 from https://eur-lex.europa.eu/legal-content/EN/ TXT/?uri=LEGISSUM:124152.

European Commission. (2015). Communication from the Commission to the European Parliament, the Council, the European Economic and Social Committee and the Committee of the Regions: a digital single market strategy for Europe (COM/2015/0192).

Filmex. (2019a). Avoimuusraportti. Retrieved 13.03.2021 from https://www. filmex.fi/site/assets/files/1152/avoimuusraportti_2019.pdf.

Filmex. (2019b). Yle-arkisto tilitysohjesääntö. Retrieved 13.03.2021 from https:// www.filmex.fi/site/assets/files/1152/tilitysohjesaanto-29_3_2019.pdf.

Filmex. (2021). General principles governing Filmex. Retrieved 13.03.2021 from https://www.filmex.fi/toiminta.

FMU. (2018). Organizational cooperation. Retrieved 13.03.2021 from https:// www.muusikkojenliitto.fi/info.

FMU. (2021). Musicians' union tariffs. Retrieved 13.03.2021 from https://www.muusikkojenliitto.fi/wp-content/uploads/2021/02/ Liksalista_2021_ENG_v2.pdf.

Gans, J. (2012). Information wants to be shared. Harvard Business Review Press.

GDA. (2019). Relatório de atividades. Retrieved 13.03.2021 from https://www. gda.pt/wp-content/uploads/2020/10/RELATORIO_GDA_2019_FINAL. pdf.

Gedipe. (2020a). Relatorio transparencia. Retrieved 13.03.2021 from https:// www.gedipe.org/site_gedipe/main/Documento? $i=338 \& s=5$.

Gedipe. (2020b). Tabela universal: direitos de retransmissão por cabo ou meios similares de retransmissão, tarifário e escalões. Retrieved 13.03.2021 from https:// www.gedipe.org/site_gedipe/main/Documento? $\mathrm{i}=369 \& \mathrm{~s}=12$.

Gedipe. (2021). Regulamento de reclamações e resolução de litígios. Retrieved 13.03.2021 from https://www.gedipe.org/site_gedipe/main/ Documento? $\mathrm{i}=381 \& s=14$.

Gilbert, K. (2009). The valuation of copyright-related intangible assets. Insights, 35-46.

Gramex. (2019a). Gramexin avoimuus raportti vuodelta. Retrieved 13.03.2021 from https://www.gramex.fi/wp-content/uploads/2018/10/Avoimuusraportti-painoversio_FI_2020_low.pdf.

Gramex. (2019b). Vuosikatsaus. Retrieved 13.03.2021 from https://www. gramex.fi/wp-content/uploads/2020/06/Vuosikatsaus-2019-FINAL_low. pdf. 
Gramex. (2021a). Handling of complaints and settlement. Retrieved 13.03.2021 from https://www.gramex.fi/portfolio-items/yhteishallinnointiin-liittyvien-valitusten-kasittely-ja-riitojen-ratkaiseminen.

Gramex. (2021b). Online store. Retrieved 13.03.2021 from https://shop.gramex. fi/fi/shop/av.

Hooijer, R., \& Baloyi, J.J. (2016). Collective management organizations: tool kit, neighboring rights. Retrieved 01.03.2021 from https://www.wipo.int/edocs/ pubdocs/en/wipo_pub_emat_2016_2.pdf.

IPF. (2005). Tarifo. Retrieved 13.03.2021 from https://www.ipf.si/media/1021/t-radiodifuzija.pdf.

IPF. (2018). Pogodba o pogojih. Retrieved 13.03.2021 from https://www.ipf.si/ media/1l0323/pogodba-o-pogojih-uporabe-fonogramov-pri-retransmisiji-tv-in-radijskih-programov-v-ponudbi-operaterja.pdf.

IPF. (2019). Letno porocilo. Retrieved 13.03.2021 from https://www.ipf.si/media/110686/letno-porocilo-ipf-2019.pdf.

IPF. (2021). Members and voting rights. Retrieved 13.03.2021 from https://www. ipf.si/en/creators/have-you-authorised-ipf-ko-yet/\#ipfkomembership.

Kopiosto. (2019). Kopiosto in 2019. Retrieved 13.03.2021 from https: / /www.kopiosto.fi/app/uploads/2018/11/07145025/Kopiosto-in-2019.pdf.

Kopiosto. (2020). Activities. Retrieved 13.03.2021 from https://www.kopiosto. fi/kopiosto/kopiosto/toiminta.

Kopiosto. (2021). Price list of copy channels. Retrieved 13.03.2021 from https:// www.kopiosto.fi/kopiosto/teosten-kayttajille/tv-kanavien-edelleen-lahettaminen/tv-kanavien-edelleen-lahettaminen-yhteisantenniverkoissa/ kopiosto-kanavien-hinnasto.

Kossecki, P. (2012). Metodologia określania wartości praw autorskich: kalkulacja odszkodowań do celów prawnych. E-Mentor, 3(45), 46-50.

Kossecki, P. (2014). Valuation of copyrights for law purposes: collecting societies and cable operators. http://dx.doi.org/10.2139/ssrn.2482047.

Kossecki, P. (2015). Valuation and value creation of cable tv operators: cable operators and copyright fees. PWSFTViT.

Kossecki, P. (2020). What is the value of the film copyrights: an analysis of basic methods of valuation. PWSFTViT. https://dx.doi.org/10.2139/ssrn.3580949.

Kossecki, P., Akin, O., \& Wachowicz, J., (2021). Valuation of intellectual property rights, copyrights to audiovisual works: an international comparison of copyright management organizations. Retrieved 13.03.2021 from https://papers.ssrn. com/sol3/papers.cfm?abstract_id=3968559.

LM. (2016). Möglichkeiten für beschwerden und alternative. Retrieved 13.03.2021 from https://literar.at/docs/default-source/downloads/neu-beschwerdem\%C3\%B6glichkeit.pdf?sfvrsn=ebal45e5_4.

LM. (2019). Geschäftsbericht. Retrieved 13.03.2021 from https://literar.at/ docs/default-source/downloads/gb-2019-online.pdf?sfvrsn=db05be5_2.

LM. (2021). Kabel-TV Tarif 2021. Retrieved 13.03.2021 from https://literar.at/ docs/default-source/downloads/tarife-ktv-2021.pdf?sfvrsn=4c4c58e5_6. 
LSG. (2016). LSG-Tarif für OTT TV. Retrieved 13.03.2021 from http://www. lsg.at/LSG-Tarif\%20f\%C3\%BCr\%20OTT\%20TV\%2001-2020.pdf.

LSG. (2019). Geschäftsbericht und transparenzbericht. Retrieved 13.03.2021 from https://www.lsg-interpreten.com/wp-content/uploads/Bericht_ LSG_2019_15092020_2.pdf.

LSG. (2021). Perception of ancillary copyrights GmbH publications. Retrieved 13.03.2021 from http://www.lsg.at/voe.html.

Moberly, M.D. (2014). Safeguarding intangible assets. Elsevier.

MPLC. (2019). Rightsholder licensing agreement. Retrieved 13.03.2021 from https://www.mplc.es/files/MPLC\%20Rightsholder\%20Agreement\%20 2019.pdf.

NCB. (2019). Transparency report. Retrieved 13.03.2021 from http://www.ncb. dk/pdf/TransparencyReport-2019.pdf.

NCB. (2020). Complaints and dispute resolution. Retrieved 13.03.2021 from http://www.ncb.dk/pdf/Complaints-and-disputes.pdf.

NCB. (2021). Using music in tv productions within the Nordic region. Retrieved 13.03.2021 from http://www.ncb.dk/pdf/av-pricelist-gentv-en.pdf.

Ostrom, E. (2010). Beyond markets and states: polycentric governance of complex economic systems. American Economic Review, 100(3), 641-672. https:// doi.org/10.1257/aer.100.3.641.

Pastor, D., Glova, J., Lipták, F., \& Kováč, V. (2017). Intangibles and methods for their valuation in financial terms: literature Review. Intangible Capital, 13(2), 387-410. http://dx.doi.org/10.3926/ic.752.

Rumniak, P. (2011). Procesowe podejście do wyceny składników niematerialnych. Zeszyty Naukowe Uniwersytetu Szczecińskiego, 41(668), 285-294.

SACD. (2021). Two centuries of experience. Retrieved 28.02.2021 from https:// www.sacd.fr/en/two-centuries-experience.

SAZAS. (2006). Pravilnik o javni priobčitvi glasbenih del. Retrieved 13.03.2021 from https://www.sazas.org/Portals/0/Documents/SAZAS\%20dokumenti/Pravilniki\%20in\%20statuti/Pravilnik\%20o\%20javni\%20priobcitvi\%20glasbenih\%20del.pdf.

SAZAS. (2018). Rules on the distribution. Retrieved 13.03.2021 from https:// www.sazas.org/Portals/0/Documents/Dokumenti\%20v\%20EN/InterniAkti-EN_ZKUASP/Distribution-Rules_SAZAS_ko_2018-06.pdf.

SAZAS. (2019). Аnпual report. Retrieved 13.03.2021 from https://www.sazas. org/Portals/0/Documents/Dokumenti\%20v\%20EN/Annual-Business-Report_2019-EN_SAZAS-Society-ko.pdf.

Smith, G.V., \& Parr, R.L. (2005). Intellectual property, valuation, exploitation, and infringement damages. John Willey \& Sons.

SPA. (2012). TV broadcast licensing fees. Retrieved 13.03.2021 from https:// www.spautores.pt/assets_live/5302/tv_broadcast_licensing_fees.pdf.

SPA. (2019). Relatorio E contas da direccao. Retrieved 13.03.2021 from https://www.spautores.pt/assets_live/14099/relat_rio_e_contas_da_direc_o_2019.pdf. 
SPA. (2020). Anexo ao regulamento de repartição de direitos. Retrieved 13.03.2021 from https://www.spautores.pt/assets_live/14003/tabelacomiss_es.pdf.

SPA. (2021). Quem somos. Retrieved 13.03.2021 from https://www.spautores. $\mathrm{pt} / \mathrm{spa}$ /quem-somos.

Teosto. (2018). Free-to-end user audiovisual content. Retrieved 13.03.2021 from https://www.teosto.fi/app/uploads/2021/01/15104808/free_to_enduser_ audiovisual_content_pricelist.pdf.

Teosto. (2019a). 2019 Tilinpäätös. Retrieved 13.03.2021 from https://www.teosto.fi/app/uploads/2021/02/19111514/teosto_tilinpaatos_2019_fi.pdf.

Teosto. (2019b). Avoimuusraportti 2019. Retrieved 13.03.2021 from https:// www.teosto.fi/app/uploads/2021/02/19111526/teosto_avoimuus raportti_2019_fi-1.pdf.

Teosto. (2021). Work organization. Retrieved 13.03.2021 from https://www.teosto.fi/tietoa-teostosta/organisaatio.

VAM. (2019). Transparency report. Retrieved 14.03.2021 from https://www. vam.cc/fileadmin/user_upload/Berichte/VAM_Transparenzbericht_2019_ inkl_Beurteilung_Bilanz.pdf.

VAM. (2020). Bezugsberechtigte. Retrieved 13.03.2021 from https://www.vam. cc/fileadmin/user_upload/Verzeichnisse/Bezugsberechtigte_2021_03_09_ geordnet.pdf.

VAM. (202la). Für die integrale kabelweitersendung. Retrieved 14.03.2021 from https://www.vam.cc/fileadmin/user_upload/Vertraege/Einzelvertrag_Kabelnetzbetreiber.pdf.

VAM. (2021b). Kabel TV-entgelt 2021. Retrieved 13.03.2021 from https://www. vam.cc/fileadmin/user_upload/Tarife/6_Tarif_KabelTV_VAM_2021.pdf.

VDFS. (2016). Möglichkeiten für beschwerden. Retrieved 14.03.2021 from https://www.vdfs.at/files/moeglichkeiten_fuer_beschwerden_und_alternative_streitbeilegung_2.pdf.

VDFS. (2020). Kabel-TV tarif. Retrieved 14.03.2021 from https://www.vdfs. at/files/tarife-ktv-2020.pdf.

VDFS. (2021). The members of the VdFS. Retrieved 14.03.2021 from https:// www.vdfs.at/1-0-Ueber-die-Verwertungsgesellschaft-der-Filmschaffenden.html\#DieMitgliederderVdFS.

VGR. (2016). Inquiries \& complaints. Retrieved 14.03.2021 from http://www. vg-rundfunk.at/anfragen-und-beschwerden.

VGR. (2019). Transparenzbericht. Retrieved 14.03.2021 from http://www. vg-rundfunk.at/wp-content/uploads/2020/07/Transparenzbericht-2019-VGR.pdf.

VGR. (2020). VGR tarifverlautbarung. Retrieved 14.03.2021 from http://www. vg-rundfunk.at/wp-content/uploads/2020/11/Kabel_Tarifverlautbarung_27102020.pdf.

Webster, E., \& Jensen, P. H. (2006). Investment in intangible capital: an enterprise perspective. Economic Record, 82(256), 82-96. https://doi. org/10.1111/j.1475-4932.2006.00296.x. 
WIPO. (2016). Collective management organizations: tool kit, neighboring rights. Retrieved 27.02.2021 from https://www.wipo.int/edocs/pubdocs/en/ wipo_pub_emat_2016_2.pdf.

WIPO. (2020). Berne convention for the protection of literary and artistic works. Retrieved 27.02.2021 from https://www.wipo.int/export/sites/www/treaties/en/documents/pdf/berne.pdf.

ZAMP. (2019). Letno poročilo. Retrieved 13.03.2021 from https://www. zamp-zdruzenje.si/doc/zamp-letno-porocilo-2019-spletna-objava.pdf.

ZAMP. (2020). Uradni list: vsebina uradnega lista. Retrieved 13.03.2021 from https://www.zamp-zdruzenje.si/doc/dogovor-za-ureditev-medsebojnihrazmerij-v-zvezi-z-uporabo-avtorskih-del-med-zkos-ter-zsodt-na-eni-strani-ter-zamp-uradni-list-1082-27-2016.pdf.

ZAMP. (2021). Membership in ZAMP. Retrieved 13.03.2021 from https://www. zamp-zdruzenje.si/avtorji/vclanitev.html.

\section{Acknowledgements}

Author contributions: authors have given an approval to the final version of the article. Authors contributed to this work equally.

Funding: this research was fully funded by the Kozminski University.

Supplementary information: authors acknowledge the following institution for help with the preparation of the article: Polish National Film, Television and Theatre School and Kozminski University.

Note: the results of this study were presented at the 8th International Conference Sustainable Finance \& Accounting: Economy, Ethics, Environment (April 19-21, 2021, Torun, Poland). 


\section{Appendix}

Table 1.

Parameters related to the CMOs' market in four clusters of European countries

\begin{tabular}{|c|c|c|c|c|c|c|}
\hline No & Country & GDPpc (EUR) & CMOcol (\%) & MeanCons (EUR) & In the EU & In the euro area \\
\hline \multirow[t]{10}{*}{$\mathrm{Cl}$} & Romania & 18400 & 0.014 & 212 & Yes & No \\
\hline & Latvia & 19700 & 0.024 & 409 & Yes & Yes \\
\hline & Poland & 20500 & 0.023 & 472 & Yes & No \\
\hline & Slovakia & 22400 & 0.012 & 556 & Yes & Yes \\
\hline & Portugal & 22600 & 0.023 & 488 & Yes & Yes \\
\hline & Lithuania & 23100 & 0.015 & 433 & Yes & Yes \\
\hline & Estonia & 23200 & 0.026 & 537 & Yes & Yes \\
\hline & Czech Republic & 26400 & 0.022 & 571 & Yes & No \\
\hline & Spain & 27100 & 0.019 & 677 & Yes & Yes \\
\hline & Centroid 1 & 22600 & 0.020 & 484 & & \\
\hline \multirow[t]{5}{*}{$\mathrm{C} 2$} & Croatia & 18200 & 0.036 & 590 & Yes & No \\
\hline & Hungary & 20000 & 0.035 & 360 & Yes & No \\
\hline & Slovenia & 25100 & 0.038 & 787 & Yes & Yes \\
\hline & Italy & 28400 & 0.035 & 583 & Yes & Yes \\
\hline & Centroid 2 & 22925 & 0.036 & 580 & & \\
\hline \multirow[t]{4}{*}{$\mathrm{C} 3$} & France & 30600 & 0.053 & 1001 & Yes & Yes \\
\hline & Finland & 32100 & 0.045 & 892 & Yes & Yes \\
\hline & Denmark & 37700 & 0.050 & 1593 & Yes & Yes \\
\hline & Centroid 3 & 33467 & 0.049 & 1162 & & \\
\hline \multirow[t]{7}{*}{$\mathrm{C} 4$} & United Kingdom & 31100 & 0.032 & 1158 & No & No \\
\hline & Belgium & 34300 & 0.031 & 905 & Yes & Yes \\
\hline & Sweden & 35600 & 0.029 & 1435 & Yes & No \\
\hline & Germany & 36400 & 0.028 & 1274 & Yes & Yes \\
\hline & Austria & 37400 & 0.031 & 1215 & Yes & Yes \\
\hline & Netherlands & 37700 & 0.032 & 953 & Yes & Yes \\
\hline & Centroid 4 & 35417 & 0.031 & 1157 & & \\
\hline
\end{tabular}

Source: Own preparation based on Kossecki et al. (2021).

Table 2.

TV broadcast licensing fees of P2 (SPA) (\%)

\begin{tabular}{lcc}
\hline \multicolumn{1}{c}{ Type of channel } & Use of protected works & Licensing fee \\
\hline news, sports & $0-25$ & 0.50 \\
general interest & $25-75$ & 2.25 \\
music, movies & $75-100$ & 4.00 \\
\hline
\end{tabular}

Source: Own preparation based on SPA (2012). 
Table 3.

Cable retransmission rights of P5 (GEDIPE) (EUR)

\begin{tabular}{lc}
\hline \multicolumn{1}{c}{ Subscriber range } & Licensing fee \\
\hline $0-300,000$ & 0.156 \\
$300,000-1,000,000$ & 0.130 \\
$>1,000,000$ & 0.066 \\
\hline
\end{tabular}

Source: Own preparation based on Gedipe (2020b).

Table 4.

Variation of tariffs for commercial TV stations, CMO S2

\begin{tabular}{lc}
\hline \multicolumn{1}{c}{ Method } & Annual payment for a program (EUR) \\
\hline census & more than 200,000 \\
a sample with parts that are played every other day & more than 150,000 \\
a sample with parts that are played every fourth day & more than 100,000 \\
a sample with parts that are played every eighth day & more than 50,000 \\
a sample with parts that are played on the lst and 15th of the month & more than 20,000 \\
analogy & 20,000 or less \\
\hline
\end{tabular}

Source: Own preparation based on SAZAS (2018).

Table 5.

Price list of Fl (Kopiosto) (EUR)

\begin{tabular}{ccccccc}
\hline Channels & 1 & 2 & 3 & 4 & Swedish TVs & Additional channels \\
\hline licensing fee & 0.410 & 0.820 & 1.093 & 1.366 & 0.535 & 0.247 \\
\hline
\end{tabular}

Source: Own preparation based on Kopiosto (2021).

Table 6.

Values of synthetic indicators of CMOs for transparency

\begin{tabular}{lcccccc}
\hline \multicolumn{1}{c}{ CMOs } & $\mathrm{X}_{1}$ & $\mathrm{X}_{2}$ & $\mathrm{X}_{3}$ & $\mathrm{X}_{4}$ & $\mathrm{X}_{5}$ & $\mathrm{X}_{6}$ \\
\hline P1 & 0.000 & 0.000 & 0.000 & 0.000 & 0.000 & 0.333 \\
P2 & 1.000 & 0.750 & 0.000 & 0.333 & 0.333 & 0.667 \\
P3 & 0.000 & 0.750 & 0.000 & 0.333 & 0.333 & 0.333 \\
P4 & 0.000 & 0.000 & 0.000 & 0.000 & 0.000 & 0.333 \\
P5 & 0.333 & 1.000 & 0.500 & 0.000 & 0.667 & 0.333 \\
Portugal & $\mathbf{0 . 2 6 7}$ & $\mathbf{0 . 5 0 0}$ & $\mathbf{0 . 1 0 0}$ & $\mathbf{0 . 1 3 3}$ & $\mathbf{0 . 2 6 7}$ & $\mathbf{0 . 4 0 0}$ \\
S1 & 1.000 & 0.750 & 0.000 & 1.000 & 1.000 & 0.333 \\
S2 & 0.667 & 0.750 & 1.000 & 1.000 & 1.000 & 0.667 \\
S3 & 0.333 & 0.750 & 1.000 & 0.333 & 1.000 & 0.667 \\
S4 & 0.333 & 0.750 & 0.000 & 1.000 & 1.000 & 0.333 \\
Slovenia & $\mathbf{0 . 5 8 3}$ & $\mathbf{0 . 7 5 0}$ & $\mathbf{0 . 5 0 0}$ & $\mathbf{0 . 8 3 3}$ & $\mathbf{1 . 0 0 0}$ & $\mathbf{0 . 5 0 0}$ \\
F1 & 0.333 & 0.500 & 0.000 & 0.333 & 1.000 & 1.000 \\
F2 & 0.667 & 1.000 & 0.000 & 0.667 & 1.000 & 1.000 \\
F3 & 0.333 & 0.750 & 0.500 & 1.000 & 1.000 & 1.000 \\
F4 & 0.333 & 1.000 & 0.000 & 0.667 & 0.333 & 0.333 \\
F5 & 0.333 & 0.000 & 0.000 & 0.333 & 0.333 & 0.667
\end{tabular}




\begin{tabular}{lcccccc}
\hline \multicolumn{1}{c}{ CMOs } & $\mathrm{X}_{1}$ & $\mathrm{X}_{2}$ & $\mathrm{X}_{3}$ & $\mathrm{X}_{4}$ & $\mathrm{X}_{5}$ & $\mathrm{X}_{6}$ \\
\hline F6 & 0.333 & 1.000 & 0.500 & 0.000 & 0.667 & 0.333 \\
Finland & $\mathbf{0 . 3 8 9}$ & $\mathbf{0 . 7 0 8}$ & $\mathbf{0 . 1 6 7}$ & $\mathbf{0 . 5 0 0}$ & $\mathbf{0 . 7 2 2}$ & $\mathbf{0 . 7 2 2}$ \\
Al & 0.667 & 0.750 & 0.500 & 0.333 & 1.000 & 0.667 \\
A2 & 0.333 & 1.000 & 0.000 & 0.333 & 1.000 & 0.333 \\
A3 & 0.000 & 1.000 & 0.500 & 1.000 & 0.667 & 0.333 \\
A4 & 0.667 & 0.750 & 0.500 & 0.667 & 1.000 & 0.333 \\
A5 & 0.000 & 0.750 & 0.500 & 0.667 & 0.667 & 0.667 \\
A6 & 0.333 & 0.750 & 0.500 & 0.000 & 1.000 & 0.333 \\
Austria & $\mathbf{0 . 3 3 3}$ & $\mathbf{0 . 8 3 3}$ & $\mathbf{0 . 4 1 7}$ & $\mathbf{0 . 5 0 0}$ & $\mathbf{0 . 8 8 9}$ & $\mathbf{0 . 4 4 4}$ \\
\hline
\end{tabular}

Source: Own preparation.

Table 7.

Values of arithmetic means and standard deviations of CMOs for transparency

\begin{tabular}{ccccccc}
\hline Variable & $\mathrm{X}_{1}$ & $\mathrm{X}_{2}$ & $\mathrm{X}_{3}$ & $\mathrm{X}_{4}$ & $\mathrm{X}_{5}$ & $\mathrm{X}_{6}$ \\
\hline arithmetic average & 0.381 & 0.351 & 0.286 & 0.476 & 0.714 & 0.524 \\
standard deviation & 0.303 & 0.421 & 0.338 & 0.374 & 0.354 & 0.249 \\
\hline
\end{tabular}

Source: Own preparation.

Table 8.

Values of standardized transparency indicators of CMOs

\begin{tabular}{|c|c|c|c|c|c|c|}
\hline CMOs & $\mathrm{Z}_{1}$ & $Z_{2}$ & $\mathrm{Z}_{3}$ & $Z_{4}$ & $Z_{5}$ & $Z_{6}$ \\
\hline $\mathrm{Pl}$ & -1.256 & -0.835 & -0.845 & -1.274 & -2.017 & -0.766 \\
\hline P2 & 2.040 & 0.948 & -0.845 & -0.382 & -1.076 & 0.574 \\
\hline P3 & -1.256 & 0.948 & -0.845 & -0.382 & -1.076 & -0.766 \\
\hline P4 & -1.256 & -0.835 & -0.845 & -1.274 & -2.017 & -0.766 \\
\hline P5 & -0.157 & 1.542 & 0.634 & -1.274 & -0.134 & -0.766 \\
\hline Portugal & -0.377 & 0.354 & -0.549 & -0.917 & -1.264 & -0.498 \\
\hline $\mathrm{Sl}$ & 2.040 & 0.948 & -0.845 & 1.402 & 0.807 & -0.766 \\
\hline S2 & 0.942 & 0.948 & 2.113 & 1.402 & 0.807 & 0.574 \\
\hline S3 & -0.157 & 0.948 & 2.113 & -0.382 & 0.807 & 0.574 \\
\hline S4 & -0.157 & 0.948 & -0.845 & 1.402 & 0.807 & -0.766 \\
\hline Slovenia & 0.667 & 0.948 & 0.634 & 0.956 & 0.807 & -0.096 \\
\hline $\mathrm{Fl}$ & -0.157 & 0.354 & -0.845 & -0.382 & 0.807 & 1.914 \\
\hline $\mathrm{F} 2$ & 0.942 & 1.542 & -0.845 & 0.510 & 0.807 & 1.914 \\
\hline F3 & -0.157 & 0.948 & 0.634 & 1.402 & 0.807 & 1.914 \\
\hline F4 & -0.157 & 1.542 & -0.845 & 0.510 & -1.076 & -0.766 \\
\hline F5 & -0.157 & -0.835 & -0.845 & -0.382 & -1.076 & 0.574 \\
\hline F6 & -0.157 & 1.542 & 0.634 & -1.274 & -0.134 & -0.766 \\
\hline Finland & 0.026 & 0.849 & -0.352 & 0.064 & 0.022 & 0.797 \\
\hline $\mathrm{Al}$ & 0.942 & 0.948 & 0.634 & -0.382 & 0.807 & 0.574 \\
\hline A2 & -0.157 & 1.542 & -0.845 & -0.382 & 0.807 & -0.766 \\
\hline A3 & -1.256 & 1.542 & 0.634 & 1.402 & -0.134 & -0.766 \\
\hline A4 & 0.942 & 0.948 & 0.634 & 0.510 & 0.807 & -0.766 \\
\hline A5 & -1.256 & 0.948 & 0.634 & 0.510 & -0.134 & 0.574 \\
\hline
\end{tabular}




\begin{tabular}{lcccccc}
\hline \multicolumn{1}{c}{ CMOs } & $\mathrm{Z}_{1}$ & $\mathrm{Z}_{2}$ & $\mathrm{Z}_{3}$ & $\mathrm{Z}_{4}$ & $\mathrm{Z}_{5}$ & $\mathrm{Z}_{6}$ \\
\hline A6 & -0.157 & 0.948 & 0.634 & -1.274 & 0.807 & -0.766 \\
Austria & $\mathbf{- 0 . 1 5 7}$ & $\mathbf{1 . 1 4 6}$ & $\mathbf{0 . 3 8 7}$ & $\mathbf{0 . 0 6 4}$ & $\mathbf{0 . 4 9 3}$ & $\mathbf{- 0 . 3 1 9}$ \\
\hline
\end{tabular}

Source: Own preparation.

Table 9.

Weights for transparency indicators

\begin{tabular}{lc}
\hline \multicolumn{1}{c}{ Indicator } & Weight value \\
\hline availability of the tariff calculation and valuation information & 0.18 \\
availability of activity reports & 0.18 \\
availability of the dispute related information & 0.18 \\
availability of representation data in the market & 0.18 \\
availability of the price and financial information & 0.18 \\
availability of the information in different languages & 0.10 \\
\hline
\end{tabular}

Source: Own preparation.

Table 10.

Weighted Sums of Standardized Transparency Indicators

\begin{tabular}{|c|c|}
\hline CMOs & Weighted sum of transparency values \\
\hline $\mathrm{Pl}$ & -1.197 \\
\hline P2 & 0.181 \\
\hline P3 & -0.547 \\
\hline P4 & -1.197 \\
\hline P5 & 0.033 \\
\hline Portugal & -0.545 \\
\hline $\mathrm{S} 1$ & 0.707 \\
\hline S2 & 1.175 \\
\hline S3 & 0.657 \\
\hline S4 & 0.311 \\
\hline Slovenia & 0.712 \\
\hline $\mathrm{Fl}$ & 0.151 \\
\hline F2 & 0.723 \\
\hline F3 & 0.845 \\
\hline F4 & -0.081 \\
\hline F5 & -0.536 \\
\hline F6 & 0.033 \\
\hline Finland & 0.189 \\
\hline $\mathrm{Al}$ & 0.588 \\
\hline A2 & 0.097 \\
\hline A3 & 0.317 \\
\hline A4 & 0.615 \\
\hline A5 & 0.184 \\
\hline A6 & 0.096 \\
\hline Austria & 0.316 \\
\hline
\end{tabular}

Source: Own preparation. 
Table 11.

Values of standardized transparency indicators for pattern and anti-pattern

\begin{tabular}{lrrrrrr}
\hline \multicolumn{1}{c}{ Variable } & \multicolumn{1}{c}{$\mathrm{Z}_{1}$} & \multicolumn{1}{c}{$\mathrm{Z}_{2}$} & \multicolumn{1}{c}{$\mathrm{Z}_{3}$} & $\mathrm{Z}_{4}$ & \multicolumn{1}{c}{$\mathrm{Z}_{5}$} & $\mathrm{Z}_{6}$ \\
\hline anti-pattern & -0.226 & -0.150 & -0.152 & -0.229 & -0.363 & -0.077 \\
pattern & 0.367 & 0.278 & 0.380 & 0.252 & 0.145 & 0.191 \\
\hline
\end{tabular}

Source: Own preparation.

Table 12.

Values of the transparency measure for the CMOs

\begin{tabular}{|c|c|}
\hline CMOs & A measure of transparency \\
\hline $\mathrm{Pl}$ & 1.197 \\
\hline $\mathrm{P} 2$ & 2.370 \\
\hline P3 & 1.751 \\
\hline P4 & 1.197 \\
\hline P5 & 2.244 \\
\hline Portugal & 1.752 \\
\hline S1 & 2.817 \\
\hline S2 & 3.216 \\
\hline S3 & 2.775 \\
\hline S4 & 2.481 \\
\hline Slovenia & 2.822 \\
\hline $\mathrm{Fl}$ & 2.345 \\
\hline $\mathrm{F} 2$ & 2.831 \\
\hline F3 & 2.935 \\
\hline F4 & 2.147 \\
\hline F5 & 1.760 \\
\hline F6 & 2.244 \\
\hline Finland & 2.377 \\
\hline $\mathrm{Al}$ & 2.716 \\
\hline A2 & 2.299 \\
\hline $\mathrm{A} 3$ & 2.486 \\
\hline A4 & 2.739 \\
\hline A5 & 2.372 \\
\hline A6 & 2.298 \\
\hline Austria & 2.485 \\
\hline
\end{tabular}

Source: Own preparation. 
Table 13.

Arrangement of CMOs and their countries according to the values of the transparency measure

\begin{tabular}{lcc}
\hline & CMOs & A measure of transparency \\
\hline S2 & 2.969 \\
F3 & 2.672 \\
F2 & 2.562 \\
S1 & 2.547 \\
S3 & 2.502 \\
A4 & 2.464 \\
Al & 2.440 \\
A3 & 2.264 \\
P2 & 2.209 \\
S4 & 2.191 \\
A5 & 2.144 \\
F1 & 2.047 \\
P5 & 2.008 \\
F6 & 2.008 \\
A2 & 1.998 \\
A6 & 1.997 \\
F4 & 1.973 \\
F5 & 1.564 \\
P3 & 1.554 \\
P1 & 1.036 \\
P4 & 1.036 \\
Slovenia & 2.552 \\
Austria & 2.218 \\
Finland & 2.137 \\
Portugal & 1.569 \\
\hline
\end{tabular}

Source: Own preparation. 
